DOI: https://doi.org/10.32841/2413-2675/2020-46-6

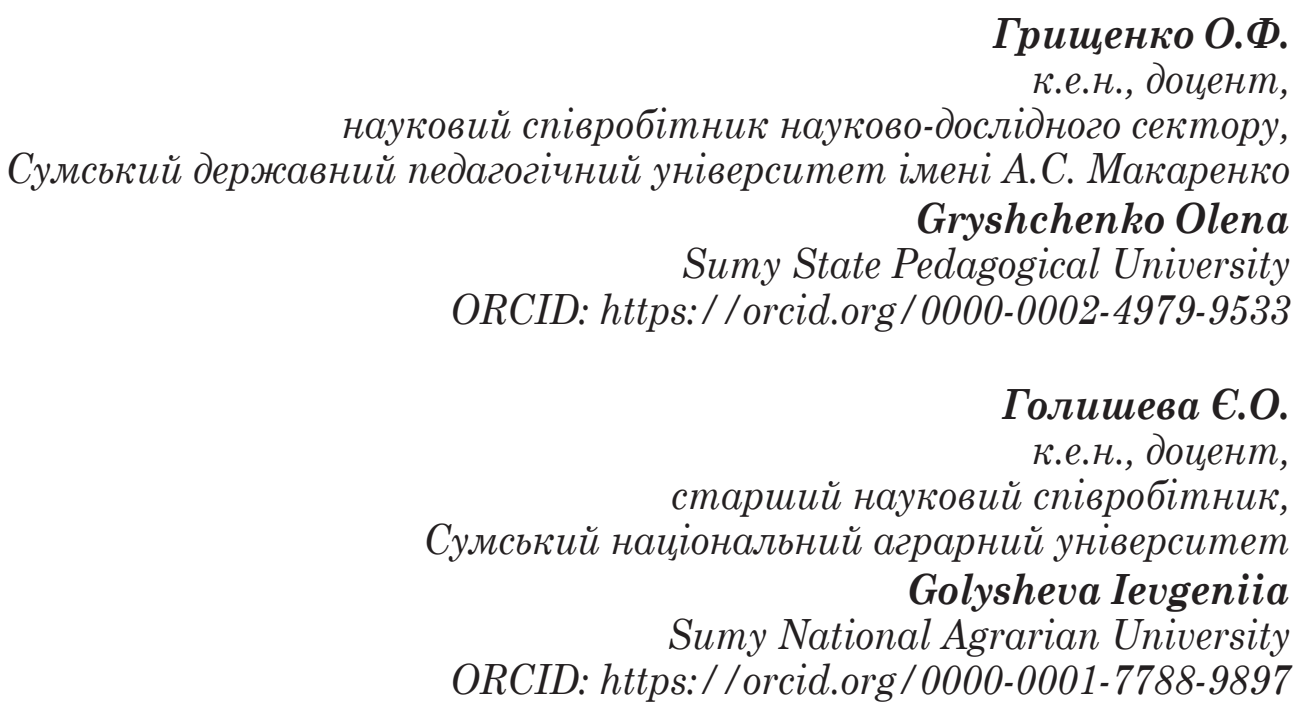

ВИКОРИСТАННЯ ГРІНВОШИНГУ ЯК ТЕХНОЛОГІЇ ЕКОЛОГІЗАЦІЇ БІЗНЕСУ: ПОНЯТТЯ, ДЕТЕРМІНАНТИ ТА ДРАЙВЕРИ ${ }^{1}$

\title{
THE USE OF GREENWASHING AS A TECHNOLOGY OF BUSINESS ECOLOGIZATION: CONCEPTS, DETERMINANTS AND DRIVERS
}

Анотація. У статті досліджено концептуальні основи трактування поняття «грінвошинг» на сучасному етапі. Авторами виконано ідентифікацію основних драйверів та детермінант грінвошингу як технології екологізації бізнесу. Проведено дослідження грінвошингу як псевдоекологічного методу управління комунікаціями суб'єктів господарської діяльності та розглянуто типи комунікацій за критерієм імплементації екологічного звернення. Виявлено і систематизовано екологічні претензії (позови) підприємств та описано прийоми екологічного маркетингу i PR, основним компонентом яких $\epsilon$ оманливі екологічні претензії. Розглянуто взаємозв'язок грінвошингу 3 результатами діяльності компанії у соціоекологічному вимірі та сформовано комплекс рекомендацій, спрямованих на боротьбу 3 грінвошингом, на рівні різних суб'єктів господарських відносин.

Ключові слова: екологізація бізнесу, грінвошинг, стратегії екологізації, екологічність.
Постановка проблеми. Сучасне бізнессередовище характеризується інтенсифікацією глобальної конкуренції та швидкими технологічними змінами, що водночас створюють як обмеження, так і можливості розвитку для підприємств. Практика вітчизняних підприємств показує, що основним чинником конкурентної боротьби залишається зниження витрат, хоча все більшу увагу приділяється впровадженню заходів щодо поліпшення сервісу споживачів та якості продукції, постійному покращенню продуктів та технологій (безперервні інновації та випереджаючі стратегії розвитку), діджиталізації бізнес-процесів, продукуванню нових знань, упровадженню сталих ініціатив та екологізації бізнесу.

Основними поштовхами до екологізації є потреба у створенні позитивного іміджу бізнесу в очах стейкхолдерів (споживачів,

\footnotetext{
${ }^{1}$ Робота виконана за рахунок бюджетних коштів МОН України, наданих на виконання науково-дослідної теми «Соціально-етичний маркетинг як інструмент забезпечення сталого розвитку» (№ ДР 0120U100884).
} 
персоналу, акціонерів, інвесторів тощо) та контактних аудиторій, а також нагальна необхідність в економії матеріальних і енергетичних ресурсів.

Загалом можна виокремити такі стратегії екологізації:

- стратегія всеосяжної екологічності («зеленим» $є$ не тільки продукт, а й технологія його виробництва, а підприємство визначає екологічність як філософію розвитку);

- стратегія «зелених» інновацій (підприємство, маючи достатні активи та досвід у створенні інноваційних продуктів, орієнтується на створення «зелених» інновацій різного типу та рівня новизни з нуля);

- стратегія «зеленого» продукту (підприємство робить акцент на чистоті та екологічності продукції, технологічний та ресурсний аспекти можуть навмисно замовчуватися або нівелюватися).

На жаль, сучасні підприємства, розуміючи конкурентні переваги та можливості розвитку, що забезпечує екологізація, усе частіше видають прагнення до екологізації за демонстрацію псевдоекологічної активності. Така технологія екологічного позиціонування підприємства, товару чи послуги без достатньої доказової бази отримала назву грінвошінг (greenwashing), або зеленого камуфляжу.

Аналіз останніх досліджень і публікацій. Вивченню теоретичних і практичних аспектів грінвошингу присвячено роботи багатьох вітчизняних та закордонних дослідників, зокрема $[2-5 ; 7-12 ; 15 ; 18 ; 19]$. Проте переважну більшість досліджень здійснено закордонними дослідниками, а вітчизняні публікації обмежуються використанням описових методів аналізу і не спрямовані на формування стратегічних рішень у сфері екологізації.

Так, [16] визначає грінвошинг як дезінформацію, розповсюджену бізнес-одиницею з метою просування екологічно відповідального іміджу громадськості, а також як публічний образ екологічної відповідальності, проголошений підприємством, але сприйнятий як необгрунтований або такий, що навмисно вводить в оману. У [9] грінвошинг розглядається як практика використання інструментів PR, маркетингу та реклами $з$ метою висловлення необгрунтованої або оманливої претензії щодо переваг продукту чи послуги на основі принципів сталого розвитку. Відповідно до [10], грінвошинг можна охарактеризувати як явище, коли компанії або організації витрачають значну кількість ресурсів iз метою переконання громадськості, що вони є екологічно відповідальними, але насправді не дотримуються бізнес-практик, які зводять до мінімуму їхній негативний вплив на навколишнє середовище. Використовуючи прийоми грінвошингу, компанії або організації намагаються отримати прибуток від зростання лояльності споживачів до їхніх екологічних ініціатив, одночасно відволікаючи увагу від негативного впливу на навколишнє середовище, який виникає у результаті їх господарювання.

У [14] зазначається, що грінвошинг $\epsilon$ феноменом соціально та екологічно деструктивних компаній, які намагаються зберегти і розширити свої ринки, видаючи себе за «друзів» навколишнього середовища і лідерів боротьби за викорінення злиднів. Слід також відзначити, що грінвошинг не слід позиціонувати як спотворені комунікації, це передусім професійно-розроблений комплекс маркетингу, лейтмотивом якого $є$ зростаюча стурбованість споживачів про навколишнє середовище.

У [2] зауважують, що грінвошінг використовується для підтримки іміджу екологічно орієнтованої компанії, отримання політичної підтримки, збільшення продажів.

Мета статті. Головною метою цієї роботи $\epsilon$ дослідження негативних впливів грінвошингу як технології екологізації бізнесу на розвиток сталої економіки та екологічної свідомості споживачів.

Виклад основного матеріалу. У загальному розумінні активне масштабування грінвошингу підприємствами у сучасних умовах здебільшого пов'язане зі зростаючим попитом на екологічні продукти та послуги з боку суспільства, а також із тим, що підприємства намагаються відповісти на цей попит усіма можливими способами, не маючи досвіду, достатніх ресурсів або бажання діяти екологічно свідомо. Так, у [7] характеризують грінвошинг як поєднання 
двох форм організаційної поведінки: недотримання норм екологічної поведінки та фіктивні позитивні комунікації про екологічну поведінку (рис. 1).

Також науковці пропонують таку типологію комунікацій компаній за критерієм імплементації екологічного звернення.

Опитування Nielsen наприкінці 2015 р. показало, що 66\% світових споживачів готові платити більше за екологічні продукти, причому серед споживачів-міленіалів ця кількість зростає до 72\% [9; 10]. 3 іншого боку, дослідження Reuters [4; 11] показало, що лише 7\% людей вірять у спілкування компаній щодо стійкості, причому на 56\% вони лояльніші до брендів, які можуть швидко показати докази своєї дії.

На основі $[7 ; 15 ; 18]$ можна сформувати перелік основних драйверів (факторів розвитку) грінвошингу (рис. 2).

Грінвошинг як технологія екологізації зазвичай має на меті формування оманливої екологічної претензії (позову) на рівні підприємства, товару або послуги 3 використанням комунікаційних прийомів і текстових аргументів, які прямо чи неявно посилаються на екологічні переваги товару або послуги. На основі $[5 ; 8 ; 12 ; 19]$ авто-
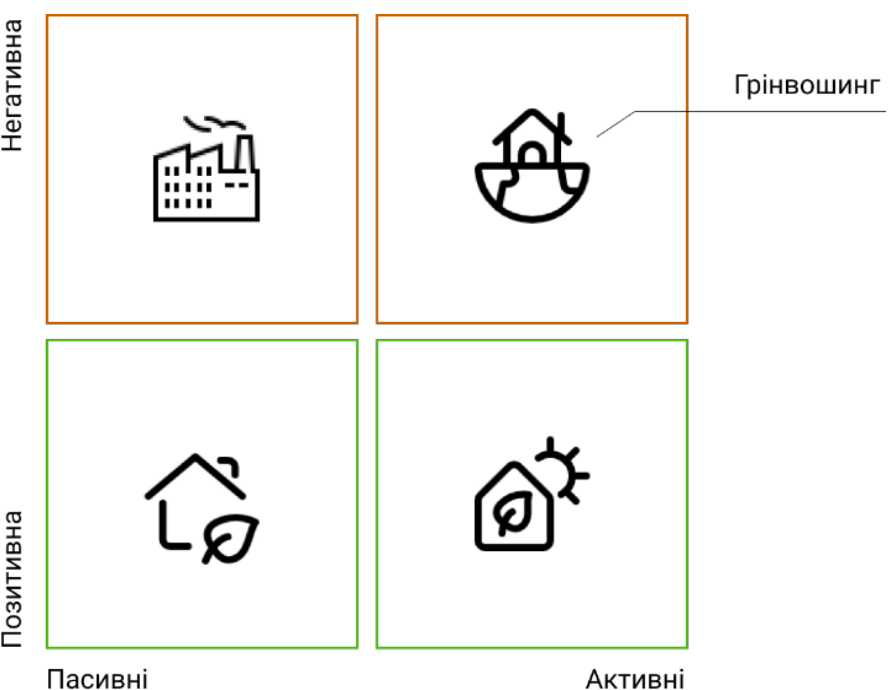

Пасивні

Активні

Рис. 1. Грінвошинг як форма організаційної поведінки

Джерело: сформовано авторами на основі [7]

рами здійснено систематизацію екологічних претензій (позовів) підприємств (табл. 2).

3 огляду на те, що все більше компаній використовують екологічний маркетинг та PR, переслідуючи мету відповідності цінностям споживачів щодо навколишнього середовища та сталого розвитку, розпізнання оманливих екологічних претензій $є$ дуже актуальним.

У [17] описано прийоми екологічного маркетингу та PR, основним компонентом яких є оманливі екологічні претензії:

Таблиця 1

Типи комунікацій за критерісм імплементації екологічного звернення

\begin{tabular}{|l|l|}
\hline \multicolumn{1}{|c|}{ Тип комунікації } & \multicolumn{1}{c}{ Деталі } \\
\hline $\begin{array}{l}\text { Помилковий } \\
\text { грінвошинг }\end{array}$ & $\begin{array}{l}\text { До цієї категорії належать компанії, які доклали значних зусиль для поліпшення екологічних } \\
\text { показників своєї продукції та процесів, але не можуть ефективно провадити комунікації про ці } \\
\text { зусилля. Такі компанії можуть оптимізувати та трансформувати свої комунікації, точно фокусуючи } \\
\text { свої повідомлення на ключових впливах, підкріплених даними. }\end{array}$ \\
\hline $\begin{array}{l}\text { Необгрунтований } \\
\text { грінвошинг }\end{array}$ & $\begin{array}{l}\text { па перший погляд, ці компанії орієнтуються на позитивні зміни та відкрито надають докази для } \\
\text { пусильрдення своїх екологічних претензій. Однак під час більш детального аналізу можна без } \\
\text { свої інтереси, намагаючись чинити вплив на екологічну політику (наприклад, у формі спонсорингу, } \\
\text { грантингу та політичного лобіювання), або може вкладати більше ресурсів у свої комунікації, } \\
\text { ніж реальні екологічні ініціативи. Ключовим ризиком такої моделі комунікацій }- \text { викриття } \\
\text { необгрунтованого грінвошингу є питанням часу, оскільки громадськість стає більш освіченою та } \\
\text { чутливою до питань екології та екологізації. }\end{array}$ \\
\hline $\begin{array}{l}\text { Грінвошинговий } \\
\text { шум }\end{array}$ & $\begin{array}{l}\text { До цієї категорії належать компанії, комунікації яких побудовані на основі необгрунтованих } \\
\text { екологічних претензій. Іншими словами -це неетичні комунікації. }\end{array}$ \\
\hline $\begin{array}{l}\text { Ефективні } \\
\text { екологічні } \\
\text { комунікації }\end{array}$ & $\begin{array}{l}\text { До цієї категоріїналежать компанії, що всебічно поліпшують екологічну та соціальну ефективність } \\
\text { своєї діяльності, продукції та узгоджують екологічні зусилля з різними функціями в компанії. } \\
\text { Комунікації будуються так, щоб споживачі та контактні аудиторії чітко розуміли взаємозв’язки } \\
\text { та наслідки, а інші компанії брали приклад. Такі компанії виступають тредсеттерами та лідерами } \\
\text { думок у всіх аспектах формування позитивної екологічної моделі поведінки суспільства. }\end{array}$ \\
\hline
\end{tabular}

Джерело: сформовано авторами на основі [7] 


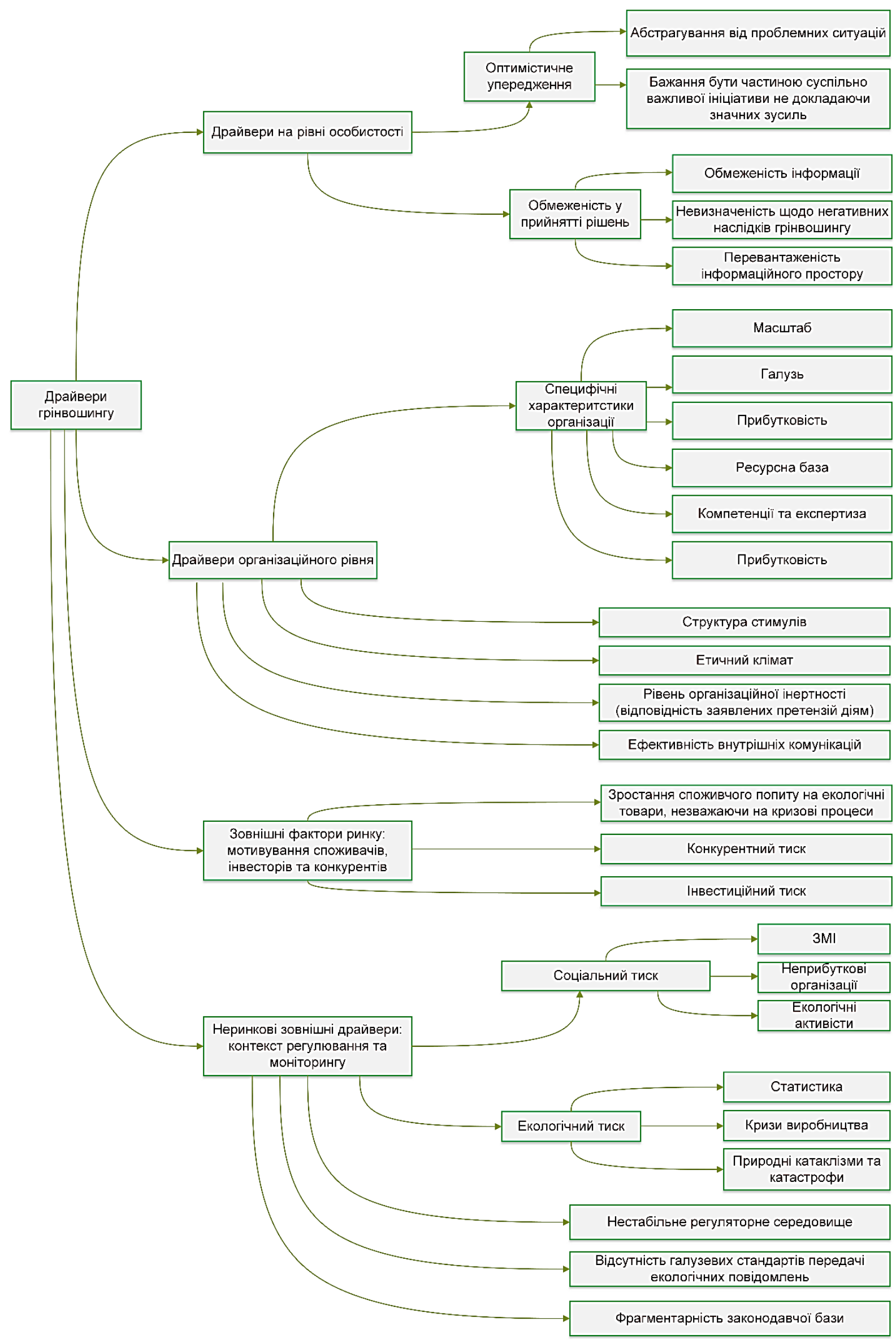

Рис. 2. Драйвери грінвошингу

Джерело: сформовано авторами на основі [7; 15; 18$]$ 
Види екологічних претензій (позовів)

\begin{tabular}{|l|l|}
\hline \multicolumn{1}{|c|}{ Вид претензії (позову) } & \multicolumn{1}{|c|}{ Са об’єктом, на який посилаються екологічні позови } \\
\hline \multicolumn{2}{|l|}{} \\
\hline Продуктова & Акцент на екологічних властивостях товару \\
\hline Процесна & $\begin{array}{l}\text { Акцент на високих/позитивних екологічних показниках технологічного процесу } \\
\text { виробництва та/або методі екологічної утилізації }\end{array}$ \\
\hline Іміджева & $\begin{array}{l}\text { Акцент на підвищенні екологічного іміджу організації, зазвичай шляхом асоціювання } \\
\text { організації з екологічною ініціативою чи діяльністю, яка має підвищену громадську } \\
\text { підтримку чи соціальний ефект }\end{array}$ \\
\hline Експертно-реферативна & $\begin{array}{l}\text { Створення від імені підприємства незалежного твердження щодо навколишнього } \\
\text { середовища у цілому або його стану в окремій галузі, яке нібито засноване на фактах }\end{array}$ \\
\hline Комбінована & Комбінація двох або більше претензій у рамках даного класифікаційного підходу \\
\hline \multicolumn{2}{|l|}{ За специфікою оманливості претензії } \\
\hline Нечіткі/неоднозначні & $\begin{array}{l}\text { Використання тверджень, які є розмитими, неоднозначними, занадто широкими та/або не } \\
\text { мають чіткого визначення }\end{array}$ \\
\hline Упущення & $\begin{array}{l}\text { Використання тверджень, у яких навмисно відсутня необхідна інформація для оцінки їі } \\
\text { дійсності }\end{array}$ \\
\hline Фальсифікація & Використання неточних, вигаданих або фальсифікованих тверджень \\
\hline Прийнятно оманливі & $\begin{array}{l}\text { Використання тверджень, які не містять оманливих ознак але згладжують певні незручні } \\
\text { факти }\end{array}$ \\
\hline Комбінована & Комбінація двох або більше претензій у рамках даного класифікаційного підходу \\
\hline
\end{tabular}

Джерело: сформовано авторами на основі [5; 8; 12; 19]

- оманливий маркетинг (у своїх комунікаціях компанії покладаються на зловживання «екожаргоном» для просування неправдиво екомаркованих товарів чи послуг, які апелюють до соціальної свідомості споживачів та приносять прибуток);

- екомаскування (у своїх комунікаціях компанії акцентують увагу споживачів та контактних аудиторій на одній нагальній проблемі (наприклад, відмова від пластику у пакуванні продукту) i, таким чином, зміщують акцент від інших слабких сторін компанії, пов'язаних $з$ екологією і сталим розвитком);

- екологічні претензії як частина бізнес-моделі (дана тактика переважно орієнтується на прибуток і служить для використання на свою користь імпульсу поведінки споживачів, керованої екологічною свідомі- стю. Так, компанії наголошують на співпраці з некомерційними організаціями, спонсоруванні або грантуванні, щоб відволікти споживачів від їхньої неетичної ділової практики).

Грінвошинг також тісно пов'язаний iз кліматичним лобіюванням інтересів підприємств у напрямі кліматично позитивного брендингу. Так, наприклад, за даними Bloomberg [6], у нафтогазовому секторі щорічні витрати на кліматичне лобіювання п'яти найбільших державних компаній становлять 201 млн доларів, окрім того додатково витрачено 195 млн доларів на позитивний кліматичний брендинг.

У табл. 3 охарактеризовано основні складники, що характеризують взаємозв'язок грінвошингу з результатами діяльності компанії у соціоекологічному вимірі.

Таблиця 3

Взаємозв'язок грінвошингу з результатами діяльності компанії у соціоекологічному вимірі

\begin{tabular}{|c|c|c|}
\hline Складник & $\begin{array}{c}\text { Рівень інтенсивності рінвошингу } \\
\text { (комунікації з претензіями на } \\
\text { сталий розвиток) }\end{array}$ & $\begin{array}{c}\text { Діяльність компанії } \\
\text { у соціоекологічному вимірі }\end{array}$ \\
\hline Втрачена вигода & Низький & Максимальна активність \\
\hline Репутаційні ризики & Високий & Мінімальна активність \\
\hline Стагнація & Низький & Мінімальна активність \\
\hline Конкурентна перевага & Високий & Максимальна активність \\
\hline
\end{tabular}

Джерело: сформовано авторами на основі [3] 
Висновки і пропозиції. У рамках даного дослідження автори наголошують на тому, що грінвошинг слід розуміти не як драйвер, а як бар'єр розвитку сталої економіки. Підприємства у гонитві за економічними вигодами все більше вдаються до імплементації технологій грінвошингу у рамках стратегій екологізації, чим у довгостроковій перспективі уповільнюють зусилля щодо сталого розвитку, роблячи все більше людей скептичними до екологічних ініціатив.

Грінвошинг також виступає обмежуючим чинником у процесі побудови у споживачів шаблонів екологічно свідомої поведінки та значно спотворює факти у процесі прийняття споживацьких рішень. У масиві інформації про продукти та послуги споживачі повинні не тільки оцінити всі їх переваги та недоліки, а й розпізнати неправдиві твердження та необгрунтовані претензії. За таких умов деякі компанії активно інвестують в екологічний імідж, упроваджуючи екологічні ініціативи, та запроваджують екологічні тренди, а інші компанії зосереджуються тільки на претензіях, не створюючи жодного практичного підгрунтя.

Слід також відзначити, що деструктивним аспектом грінвошингу $є$ те, що час та ресурси, які можна було б краще витратити на ініціативи з позитивним впливом на навколишнє середовище, використовуються на створення псевдоекологічних ініціатив.

На нашу думку, ключовою проблемою є те, що для регулювання грінвошингу не розроблено вичерпної нормативної бази навіть у найрозвиненіших країнах світу. Так, точковими є стандарти щодо запобігання або обмеження практики грінвошингу, не існує галузевих стандартів передачі екологічних повідомлень, розвиток системи законодавчого регулювання навмисно гальмується 3 подачі світових бізнес-гігантів. Усе це сприяє експоненційному зростанню обсягів грінвошингу. I якщо дана тенденція продовжиться без будь-якого регуляторного впливу, поступово довіра споживачів буде підірвана, що призведе до недовіри та підозри щодо будьякої зеленої реклами. Ураховуючи все вищезазначене, авторами сформовано комплекс рекомендацій, спрямованих на боротьбу 3 грінвошингом на рівні різних суб'єктів господарських відносин (споживачів, підприємців, контролюючих органів).

Так, споживачам рекомендується використовувати аналітичний стиль прийняття рішень, який, своєю чергою, має ставити під сумнів будь-які екологічні претензії підприємців. Прийняте споживацьке рішення повинне базуватися на міцній доказовій базі про відповідність дійсності екологічних претензій підприємств. Джерелами формування такої доказової бази можуть стати авторитетні екологічні міжнародні організації та фонди (Greenpeace, Ecolabel Index, CorpWatch тощо), міжнародні сертифікаційні організації (ISO), незалежні дослідницькі фонди та програми тощо.

Підприємцям рекомендується звернути увагу на те, що, з одного боку, грінвошинг приносить вигоди, але, з іншого боку, у довгостроковій перспективі може призвести до втрати репутації, упущеної вигоди, нарощення технологічного боргу. Тому комунікація підприємців повинна будуватися на принципах прозорості, чесності, обгрунтованості, відкритості та готовності визнавати помилки. Послуговуючись вищезазначеними принципами, підприємства повинні підкріпляти усі свої претензії відповідними даними, справжніми екологічними товарами і послугами, сертифікатами та незалежними експертними висновками, а також робити надбанням громадськості не лише позитивні впливи підприємницької діяльності на навколишнє середовище, а й негативні. Компанії повинні здійснювати аудит життєвого циклу та виявити ступінь і характер впливу всіх своїх продуктів на навколишнє середовище протягом усього життєвого циклу.

Контролюючим органам доцільно імплементувати модель державно-приватного партнерства, за якої урядові та приватні органи спільно розробляють всеохоплюючі та жорсткі стандарти і норми, спрямовані на стримування грінвошингу, у формі уніфікованих указівок, безкомпромісного моніторингу, нагляду та покарання. Особливу увагу також слід приділяти заходам, що спрямовуються на підвищення рівня обізнаності суспільства щодо грінвошингу, на 
формування та розвиток екологічно орієнтованої системи цінностей серед споживачів та підприємців.

\section{Лimepamypa:}

1. Притужалова О.А. Истинно экологический маркетинг и «псевдо-зеленый» маркетинг - гринвошинг. URL: http://ecovestnik.ru/index.php/2013-07-07-02-13-50/nashipublikacii/2324-istinno-ekologicheskij-marketing-i-psevdozelenyj-marketing-grinvoshing (дата звернення: 20.09.2020).

2. Щолокова Е.М., Дивак В.В. Дослідження грінвошінга в маркетингу. Вісник Приазовського державного технічного університету. Серія «Економічні науки». 2013. № 26. C. 126-130. DOI: https://doi.org/10.31498/2225-672 5.26.2013.32157.

3. Aggarwal Priyanka, Kadyan Aarti. Greenwashing: The Darker Side Of CSr. Indian Journal of Applied Research. 2011. № 4. P. 61-66. DOI: 10.15373/2249555X/MAR2014/20.

4. Bart King. Survey Suggests Brands Risk Greenwashing Backlash. Reuters. 2011. URL: https://www.reuters.com/ article/idUS297296127920325 (дата звернення: 16.09.2020).

5. Baum L. It's Not Easy Being Green ... Or Is It? A content analysis of environmental claims in magazine advertisements from the United States and United Kingdom. Environ Commun. 2012. № 6(4). P. 423-440. URL: https://doi.org/ 10.1080/17524032.2012.724022.

6. Bloomberg. URL: https://www.bloomberg.com/news/articles/ 2020-02-19/greenwashing-is-going-to-get-more-expensivegreen-insight (дата звернення: 10.10.2020).

7. Delmas M.A., Burbano V. The Drivers of Greenwashing. California management review. 2011. Vol. 54. № 1. P. 64-87. URL: https://www0.gsb.columbia.edu/mygsb/faculty/resea$\mathrm{rch} /$ pubfiles/14016/cmr5401 printversion delmasburbano.pdf (дата звернення: 20.09.2020).

8. Carlson L., Grove S.J., Kangun N. A content analysis of environmental advertising claims: a matrix method approach. J Advert. 1993. № 22(3). P. 27-39.

9. Caroline Sylger Jones. Greenwashing Explained. NOW Transforming Hospitality. 2017. URL: https://www.itmustbenow.com/ feature/our-big-questions/greenwashing-explained (дата звернення: 11.09.2020).

10. Chantal Verdonschot. The deceiving art of greenwashing. Idealism101. URL: https://idealism101.com/the-deceivingart-of-greenwashing/ (дата звернення: 20.09.2020).

11. Claire Powell. Greenwashing, and how to avoid it. Research world. 2020. URL: https://www.researchworld.com/ greenwashing-and-how-to-avoid-it/ (дата звернення: 08.11.2020).

12. de Freitas Netto S.V., Sobral M.F.F., Ribeiro A.R.B. et al. Concepts and forms of greenwashing: a systematic review. Environ Sci Eur. 2020. № 32. P. 19. DOI: https://doi.org/ 10.1186/s12302-020-0300-3.

13. Ecolabel Index. URL: http://www.ecolabelindex.com/ (дата звернення: 15.09.2020).

14. Greenwash Fact Sheet. CorpWatch. 2001. URL: https:/corpwatch.org/article/greenwash-fact-sheet (дата звернення: 20.09.2020).

15. Menno D.T. de Jong, Gabriel Huluba, Ardion D. Beldad. Different Shades of Greenwashing: Consumers' Reactions to Environmental Lies, Half-Lies, and Organizations Taking Credit for Following LegalObligations. Journalof Business and Technical Communication. 2019. Vol. 34. Issue 1. Pp. 38-76. DOI: https://doi.org/10.1177/1050651919874105.
16. Oxford English Dictionary. 2018. URL: https://www.oed.com/ (дата звернення: 05.11.2020).

17. Pratiksha Gurung. Why Is Greenwashing Still Trending in 2020? Climate Conscious. 2020. URL: https://medium.com/ climate-conscious/why-is-greenwashing-still-trending-in2020-42cfl fa887e1 (дата звернення: 24.11.2020).

18. Rina Horiuchi, Ryan Schuchard, Lucy Shea, Solitaire Townsend. FuterraUnderstanding and Preventing Greenwash: A Business Guide. 2009. URL: https://www.bsr.org/reports/ Understanding\%20_Preventing_Greenwash.pdf (дата звернення: 24.11.2020).

19. Tateishi E. Craving gains and claiming "green" by cutting greens? An exploratory analysis of greenfield housing developments in Iskandar Malaysia. J Urban Aff. 2017. № 40(3). Pp. 370-393. DOI: https://doi.org/10.1080/073521 66.2017 .1355667$.

\section{References:}

1. Prituzhalova O.A. (2013) Istinno ekologicheskiy marketing i «psevdo-zelenyy» marketing - grinvoshing [True green marketing and pseudo green marketing is greenwashing]. Ecological Bulletin of Russia [Ekologicheskiy vestnik Rossii]. Available at: http://ecovestnik.ru/index.php/2013-07-07-02-13-50/ nashi-publikacii/2324-istinno-ekologicheskij-marketingi-psevdo-zelenyj-marketing-grinvoshing (accessed 20 September 2020).

2. Shchekolova Ie.M., Dyvak V.V. (2013) Doslidzhennya hrinvoshinha v marketynhu [Greenwashing research in marketing]. Visnyk pryazovs'koho derzhavnoho tekhnichnoho universytetu. Seriya: ekonomichni nauky [Bulletin of the Azov State Technical University. Series: economic sciences], no. 26, pp. 126-130. DOI: https://doi.org/10.31498/2225-6725.26.2013.32157.

3. Aggarwal Priyanka, Kadyan Aarti (2011). Greenwashing: The Darker Side Of CSr. Indian Journal of Applied Research, no. 4, pp. 61-66. DOI: 10.15373/2249555X/MAR2014/20.

4. Bart King (2011) Survey Suggests Brands Risk Greenwashing Backlash. Reuters. Available at: https://www.reuters.com/article/idUS29726127920110325 (accessed 16 September 2020).

5. Baum L (2012) It's Not Easy Being Green ... Or Is It? A content analysis of environmental claims in magazine advertisements from the United States and United Kingdom. Environ Commun, no. 6(4), pp. 423-440. DOI: https://doi.org/10.1080/ 17524032.2012 .724022

6. Bloomberg. Available at: https://www.bloomberg.com/news/ articles/2020-02-19/greenwashing-is-going-to-get-more-expensive-green-insight (accessed 10 October 2020).

7. Delmas M.A., Burbano V. (2011) The Drivers of Greenwashing. California management review, vol. 54, no. 1, pp. 64-87. Available at: https://www0.gsb.columbia.edu/mygsb/ faculty/research/pubfiles/14016/cmr5401 04 printversion delmasburbano.pdf (accessed 20 September 2020).

8. Carlson L., Grove S.J., Kangun N. (1993) A content analysis of environmental advertising claims: a matrix method approach. J Advert, no. 22(3), pp. 27-39.

9. Caroline Sylger Jones (2017) Greenwashing Explained. NOW Transforming Hospitality. Available at: https://www.itmustbenow.com/feature/our-big-questions/greenwashing-explained/ (accessed 11 September 2020).

10. Chantal Verdonschot. The deceiving art of greenwashing. Idealism101. Available at: https://idealism101.com/the-deceiving-art-of-greenwashing/ (accessed 20 September 2020).

11. Claire Powell (2020) Greenwashing, and how to avoid it. Research world. Available at: https://www.researchworld.com/ greenwashing-and-avoid-it/ (accessed 08 November 2020). 
12. de Freitas Netto S.V., Sobral M.F.F., Ribeiro A.R.B. et al. (2020) Concepts and forms of greenwashing: a systematic review. Environ Sci Eur, no. 32, p. 19. DOI: https://doi. org/10.1186/s12302-020-0300-3.

13. Ecolabel Index. Available at: http://www.ecolabelindex.com/ (accessed 15 September 2020).

14. Greenwash Fact Sheet. CorpWatch. 2001. Available at: https://corpwatch.org/article/greenwash-fact-sheet (accessed 20 September 2020)

15. Menno D.T. de Jong, Gabriel Huluba, Ardion D. Beldad (2019) Different Shades of Greenwashing: Consumers' Reactions to Environmental Lies, Half-Lies, and Organizations Taking Credit for Following Legal Obligations. Journal of Business and Technical Communication. Volume 34, Issue 1. pp. 38-76. DOI: https://doi.org/10.1177/1050651919874105.
16. Oxford English Dictionary. 2018. Available at: https://www.oed.com/ (accessed 05 November 2020).

17. Pratiksha Gurung (2020). Why Is Greenwashing Still Trending in 2020? Climate Conscious. Available at: https://medium.com/climate-conscgreenwashing-still-trending-in-2020-42cf1 fa887e1 (accessed 24 November 2020).

18. Rina Horiuchi, Ryan Schuchard, Lucy Shea, Solitaire Townsend. Futerra (2009). Understanding and Preventing Greenwash: A Business Guide. Available at: https://www.bsr.org/ reports/Understanding\%20_Preventing_Greenwash.pdf (accessed 24 November 2020).

19. Tateishi E (2017). Craving gains and claiming "green" by cutting greens? An exploratory analysis of greenfield housing developments in Iskandar Malaysia. J Urban Aff, no. 40(3), pp. 370-393. DOI: https://doi.org/10.1080/073521.2017.3/55667.

Аннотация. В статье исследованы концептуальные основы трактовки понятия «гринвошинг» на современном этапе. Авторами выполнена идентификация основных драйверов и детерминант гринвошинга как технологии экологизации бизнеса. Проведено исследование гринвошинга как псевдоэкологического метода управления коммуникациями субъектов хозяйственной деятельности и рассмотрены типы коммуникаций по критерию имплементации экологического обращения. Выявлены и систематизированы экологические претензии (иски) предприятий и описаны приёмы экологического маркетинга и PR, основным компонентом которых являются обманчивые экологические претензии. Рассмотрена взаимосвязь гринвошинга с результатами деятельности компании в социоэкологическом измерении и сформирован комплекс рекомендаций, направленных на борьбу с гринвошингом на уровне различных субъектов хозяйственных отношений.

Ключевые слова: экологизация бизнеса, гринвошинг, стратегии экологизации, екологичность.

Summary. The modern business environment is characterized by intensification of global competition and rapid technological changes, which both create both limitations and opportunities for development for enterprises. The practice shows that the main factor of competition is cost reduction, although more and more attention is paid to the implementation of measures to improve customer service and product quality, continuous improvement of products and technologies (continuous innovation and advanced development strategies), digitalization of business processes, production of new knowledge, implementation of sustainable initiatives and greening of business. The main impetus for greening is the need to create a positive business image in the eyes of stakeholders (consumers, staff, shareholders, investors, etc.) and contact audiences, as well as the urgent need to save material and energy resources. In this study, the authors emphasize that greenwashing should be understood not as a driver, but as a barrier to sustainable development. In pursuit of economic benefits, businesses are increasingly resorting to greenwashing technologies as part of greening strategies, which in the long run is slowing down sustainable development efforts, making more and more people skeptical of environmental initiatives. Greenwashing is also a limiting factor in the process of building patterns of environmentally conscious behavior and significantly distorts the facts in the consumer decision-making process. In the array of information about products and services, consumers must not only assess all their advantages and disadvantages, but also recognize false claims claims. Under such conditions, some companies are actively investing in environmental image, implementing environmental initiatives and environmental trends, while other companies focus only on claims without creating any practical basis. It should also be noted that the destructive aspect of greenwashing is that the time and resources that could be better spent on initiatives with a positive impact on the environment are used to create pseudo-environmental initiatives.

Keywords: business greening, greenwashing, greening strategies, environmental friendliness. 